\title{
A review on the animal xenodiversity in Sicilian inland waters (Italy)
}

\author{
Federico Marrone, ${ }^{*}$ Luigi Naselli-Flores \\ Department of Biological, Chemical and Pharmaceutical Sciences and Technologies, University of Palermo, Via Archirafi 18, 90123, \\ Palermo, Italy \\ *Corresponding author: federico.marrone@unipa.it
}

\begin{abstract}
This paper reviews the available knowledge about faunal xenodiversity in Sicilian inland waters (Italy). The aim is to provide an updated checklist and bibliography of those non-indigenous species (NIS) which occur in the island, and to identify possible threats to its native biological diversity. Data were collected through an extensive literature search which encompassed also local journals, books, congress abstracts, and other grey literature. All the collected data were critically revised and, when possible, verified by consulting available collections or through dedicated sampling surveys. Only those data contained in reports indicating precise occurrence localities, which were confirmed by our own observations and lor by at least two independent sources including at least a peer-reviewed publication, were considered as certain. Data in literature that did not meet these criteria were considered doubtful and reported separately as unverified data. The information provided by websites has been excluded as it often contains unfounded andlor erroneous data. The fauna of Sicilian inland waters host at present 31 confirmed NIS. In addition, the presence of further 11 taxa is dubious. Among the verified data, invertebrate and vertebrate taxa are nearly equally represented, with 15 and 16 taxa, respectively. With 16 species, the phylum Chordata is by far the most represented, followed by Mollusca ( 8 species) and Arthropoda (6 species). Most of these species were detected in the last 30 years due to the lack of previous regular studies on Sicilian freshwaters. With few exceptions (e.g., the recent introduction of Xenopus laevis, the African clawed frog), NIS' effects on native biota have not extensively studied in the island yet. Although the top-down effects caused by introduced vertebrate taxa are known to deeply modify the native structure of the biota, little information is available on the impacts caused by invertebrate taxa, especially the microscopic ones. The presence in Sicily of 11 nonnative species of bony fish is probably the most impacting threat to autochthonous fauna through predation, competition and hybridisation. The results shown in the paper highlight the importance and the urgency of more exhaustive investigations on NIS in Sicilian inland waters with special regard to less charismatic taxa whose effects on the native biota have never been evaluated yet.
\end{abstract}

Key words: Biological invasions; Mediterranean biodiversity; non-indigenous species; translocated species; parautochthonous taxa; allochthonous taxa.

Received: July 2015. Accepted: September 2015.

\section{INTRODUCTION}

Biological invasions, i.e., the successful establishment of non-indigenous species (NIS) in a given area, are long known to be one of the most serious threats to the conservation of the world biological diversity. In fact, NIS are known to threat the survival of indigenous species, populations, and communities through hybridisation, competition, parasitism, predation, and the structural changes they cause to the colonised habitats (Ehrenfeld, 2010; Simberloff et al., 2013). Furthermore, they are also known to cause substantial economic damages, and can be harmful for human health (Pimentel et al., 2005, Keller et al., 2011). Although biological invasions are a pervasive global phenomenon which widely interests all the existing ecosystems, some evidences suggest that inland waters are especially prone to be invaded (Gherardi, 2007; Chandra and Gerhardt, 2008). This is possibly due to the pronounced dispersal abilities of most of inland-water taxa (Incagnone et al., 2015), to the naiveté of lakes and other inland water ecosystems to the effects of invaders owing to their evolutionary isolation (Cox and Lima, 2006), and, eventually, to the pivotal importance that these habitats have always had for the human civilisation. Anthropogenic alterations of the pre-existing biocoenoses, both in terrestrial and marine environments, are in fact known to have likely facilitated the establishment of several opportunistic newcomers (Chytrý et al., 2008; Airoldi et al., 2015; see also Boggero et al., 2014). Moreover, freshwater ecosystems are globally experiencing the highest loss of biodiversity due to human activities (Naiman and Dudgeon, 2011).

In spite of some early warnings (Elton, 1958), and of the sound evidences of the impacts that non-indigenous species have on the indigenous biota, little efforts were paid to take a census and to monitor non-indigenous species in European inland waters till the end of the XX century; in some instances, confronting alien species was even suspected to be a form of xenophobia (Simberloff, 2003). Such a delay in approaching biological invasions 
interested even those countries with a longer tradition in limnological studies, and only recently national and international studies on invasion biology have been conducted. These have led to the creation of dedicated checklists and databases, available on the web, aimed at providing a complete census of the non-indigenous biota of the continent (e.g., DAISIE: Delivering Alien Invasive Species Inventories for Europe, www.europe-aliens.org, or Aquatic alien species in German inland and coastal waters, http://www.aquatic-aliens.de/). However, the completion of an exhaustive census of the NIS is intrinsically difficult given the dynamic nature of the phenomenon, and it is especially hard for those less-charismatic taxa andlor small-bodied organisms, which are more difficult to notice or to correctly identify. Furthermore, the recent evidences that cryptic species or lineages often are the protagonists of widely overlooked cryptic invasions (Saltonstall, 2002; Marrone et al., 2011; Van Bocxlaer et al., 2015), stress the need for the implementation of molecular identification tools when dealing with biological invasions (Blanchet, 2012).

Based on all these hindering factors, the known distribution of non-indigenous species often reflects the distribution of researchers interested in invasion biology andlor taxonomists, rather than that of the organisms themselves. Such is the case of the non-indigenous biota of Sicilian inland-waters, which was to date understudied, with sparse data, often published in scarcely accessible literature. As a consequence, even in the most recent reviews addressed to the non-indigenous biota of European and Italian inland waters, Sicily has often been considered jointly with Sardinia (Nocita and Zerunian, 2007; Tricarico et al., 2010; Bianco, 2014); this approach reflects the paucity of data available for the two islands rather than any theoretical, biological, or historical reason. In some cases, Sicilian NIS were even not included in the analyses at all (Marr et al., 2013; Boggero et al., 2014). Moreover, due to the aforementioned constraints, those few studies where Sicily was considered as an independent region (Gherardi et al., 2008) show rather fragmentary checklists.

The lack of comprehensive data on NIS makes their management and control difficult. Actually, not all the introduced NIS are able to successfully establish populations in the invaded areas, and even less prove to be actually invasive (i.e., noxious to the native biota - see the tens rule, cf. Williamson, 1996). However, when the invasiveness of a certain taxon becomes evident, it is often too late to control or eradicate it in spite of the efforts invested. Accordingly, it has been suggested that the NIS are to be considered guilty until proven otherwise, and that a quick and dirty response, aimed at eliminating the NIS at their very first colonisation outset is strongly advisable and, possibly, the only way to solve the problem (Gherardi, 2006). A detailed and timely monitoring of the current xenodiver- sity and of the ongoing biological invasions is thus needed when facing the challenge of protecting the indigenous species and ecosystems from biotic homogenization.

The present paper collects and reviews all the available literature on the NIS occurring in the fauna of Sicilian inland waters, with the explicit aim to provide sound and updated baseline data for future studies and desirable management activities.

\section{METHODS}

\section{Definitions and study area}

In this paper we describe the animal xenodiversity, i.e., the diversity of the non-indigenous fauna, occurring in Sicilian inland waters (cf. Leppäkoski et al., 2002). Inland waters are here defined according to the Water Framework Directive (Directive 2000/60/EC): all standing or flowing waters on the surface of the land.

In contrast with some published papers dealing with Italian xenodiversity (Gherardi et al., 2008; Tricarico et al., 2010; Boggero et al., 2014), we are hereby considering NIS (non-indigenous species) all those taxa which are occurring outside of their natural distribution range and dispersal potential, and which were introduced to Sicily by human activities (IUCN, 2000); we are therefore here including also the translocated species, i.e., those species which are native (autochthonous) to the Italian peninsula or Sardinia but that would be naturally absent in Sicily. Within the NIS, we distinguish among those taxa introduced before the year 1500, called parautochthonous taxa, and those which were introduced in Sicily after that date, i.e., the allochthonous taxa (Gazzetta Ufficiale della Repubblica Italiana, 2015).

A further important partition is between those taxa which are present in Sicily with self-sustaining breeding populations (established species) and those which are present on the island, but whose successful breeding was not observed and that might thus not be able to constitute self-sustaining populations; the non-occasional presence of the latter is due to an ongoing introduction of specimens in the wild (sporadic species). Among the NIS, we here consider invasive species those widespread non-indigenous species that have adverse effects on the invaded habitats (cf. Gherardi, 2006).

To date, no data on the occurrence of NIS on the small-circum-Sicilian islands are available; accordingly, the present paper focuses on the Sicilian mainland only.

\section{Bibliographical review}

A checklist of the NIS reported to occur in Sicily was compiled from an extensive literature search through journals, books, congress abstracts, and other grey literature. Unfortunately, given the difficulties in exhaustively tracing 
the grey literature, we cannot exclude that some information might have been missed. All collected data were critically revised and, when possible, checked by consulting available collections or through dedicated sampling surveys. In the frame of this paper, we considered as verified data those reports indicating precise occurrence localities, which were confirmed by our own observations andlor by at least two independent sources, including at least a peerreviewed publication. The information which did not meet these criteria was here considered doubtful and the taxa were reported separately as unverified. The information provided by websites has been excluded as it often contains anecdotic andlor erroneous data.

\section{RESULTS}

\section{Updated checklist and origin of the NIS occurring in Sicilian inland waters}

The updated checklist of the NIS occurring in Sicilian inland waters is reported in Tabs. 1 to 3. Overall, 31 NIS were confirmed to be positively present in Sicily (Tabs. 1 and 2). Another group includes 11 taxa whose presence in Sicily is dubious and $\backslash$ or whose non-indigenous status in Sicily is nowadays considered controversial (Tab. 3). By taking into account only the verified data, invertebrates and vertebrates are nearly equally represented, with 15 and 16 taxa respectively. The phylum Chordata is by far the most represented, with 16 species, followed by Mollusca (8 species) and Arthropoda (6 species) (Fig. 1). Overall, the commonest source for the NIS in Sicilian inland waters is the Nearctic region, followed by the Westand East-Palaearctic subregions; only single taxa colonised Sicily from the Neotropical, Afrotropical, Oriental or Australian regions (for more details see Tabs. 1 and 2; Fig. 2). In good accordance, the vast majority of the NIS occurring in Sicily are allochthonous taxa introduced after the XVI century, with only a single mammal species being a parautochthonous taxon (i.e., the brown rat), and three taxa with no data on their first introduction (i.e., the isopod Proasellus banyulensis, and the fish Perca fluviatilis and Carassius auratus, cf. Tabs. 1 and 2).

Unfortunately, nearly no information is available on how deliberate were the introductions of most of the NIS in the inland waters of Sicily, with a few exception as the one of Gambusia holbrooki introduced in Sicily between 1925 and 1927 to keep under control malaria-spreading mosquitoes (Consoli, 1928; Veronesi et al., 1997). However, a markedly different pattern is scored between invertebrate and vertebrate taxa. With the only exception of the brown rat, Rattus norvegicus, all the remaining vertebrate taxa were likely the object of intentional introductions for ornamental, fishing, or sanitary purposes; conversely, the opposite pattern is scored among the in- vertebrates, which are mostly inconspicuous species unintentionally released in the wild along with intentionallyintroduced aquatic vertebrate species andlor ornamental plants (Mazza et al., 2015).

\section{Invertebrate NIS and putative NIS}

All the invertebrate NIS listed in Tab. 1 are known to be successfully established in Sicily, being present with locally abundant, self-sustaining populations. Among them, the oldest records are those referring to the gastropod Haitia acuta, whose arrive in Sicily dates back at least to the XIX century (Sowerby, 1873-1874), followed by the crustaceans Daphnia ambigua, D. parvula, and Proasellus banyulensis, all of them first collected in Sicily in the '80s (Calvo et al., 1993; Stoch et al., 1996; Marrone et al., 2005). All the other taxa were reported to be present on the island only in the XXI century or are even still unpublished records (Tab. 1), thus suggesting a recent significant increase in the rate of successful invasions by invertebrate NIS in Sicilian inland waters.

Among the putative NIS whose presence in Sicily is inferred from unverified data, the reports of the gastropod Helisoma anceps and of the crustacean Moina affinis are likely based on the misidentification of congener species known to occur on the island, while the report of the bivalve Corbicula fluminea from western Sicily is possibly to be ascribed to the mislabelling of a museum specimen (Tab. 3). Finally, the non-indigenous status for the gastropod Galba truncatula in Sicily is questioned by recent studies (Liberto et al., 2010) which suggest that this taxon might in fact be autochthonous on the island.

\section{Vertebrate NIS and putative NIS}

Most of the vertebrate NIS occurring in Sicily are present with established, widespread populations (Tab. 2). However, there are some exceptions: the rainbow trout, Oncorhynchus mykiss, for instance, is a sporadic species, known to be unable to breed in Sicilian inland waters. The presence of this species in the rivers of the island is to be ascribed to the ongoing release of specimens for recreational fishing. To date, no evidences of the presence of reproducing populations of the locally abundant red-eared slider, Trachemys scripta elegans, in Sicily are available, although the species is known to successfully breed in Italy and might find in Sicily suitable bioclimatic conditions for its reproduction (Ficetola et al., 2009). Finally, the case of Emys orbicularis s.l. is quite peculiar as, although no pure populations of this non-indigenous species are known to occur on the island, there are evidences of the introduction of single E. orbicularis galloitalica Fritz, 1995 specimens in Sicilian localities inhabited by the endemic Sicilian pond turtle, Emys trinacris Fritz, Fattizzo, Guicking, Tripepi, Pennisi, Lenk, Joger and Wink, 2005 (Lenk et al., 1999); 
this has led to the genetic introgression of E. orbicularis genes in eastern-Sicilian populations of E. trinacris (Vamberger et al., 2015).

The identity of some non-indigenous fish species reported to be present in Sicily is still to be ascertained
(Tabs. 2 and 3); this is the case of the pike (Esox cf. lucius), whose taxonomical identity has to be carefully checked in the light of the relatively recent description of the southern pike, Esox cisalpinus Bianco and Delmastro, 2011, and of the chub (Squalius cf. cephalus), for which

Tab. 1. List of the non-indigenous invertebrate animal species known to occur in Sicilian inland waters.

\begin{tabular}{|c|c|c|c|c|c|}
\hline Taxon & $\begin{array}{l}\text { Category } \\
\text { allochthonous vs } \\
\text { parautochthonous }\end{array}$ & Origin & $\begin{array}{l}\text { Introduction } \\
\text { intentional vs } \\
\text { unintentional }\end{array}$ & $\begin{array}{c}\text { Status } \\
\text { established } v s \\
\text { sporadic }\end{array}$ & Source(s) \\
\hline
\end{tabular}

\section{NEMATODA \\ Secernentea \\ Spirurida \\ Anguillicolae}

Anguillicola crassus Kuwahara, Niimi and Itagaki, 1974

A

Southeast Asia

$\mathrm{U}$

$\mathrm{E}$

4,12

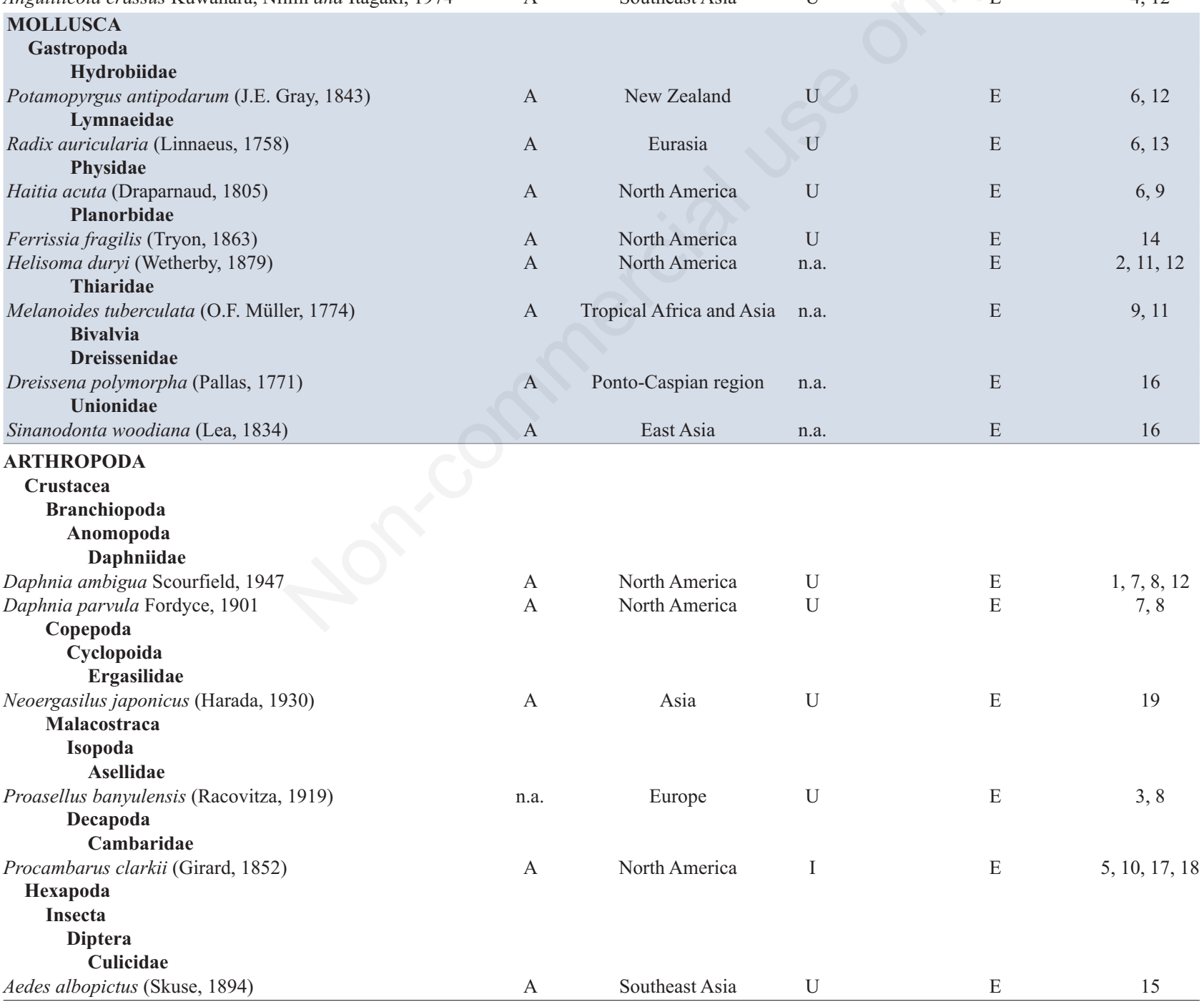

A, Allochthonous; P, parautochthonous; I, intentional; U, unintentional; E, established; S, sporadic; n.a., not available; 1, Calvo et al., 1993; 2, Manganelli et al., 1995; 3, Stoch et al., 1996; 4,Weidema, 2000; 5, D'Angelo and Lo Valvo, 2003; 6, Zettler and Richard, 2003; 7, Marrone et al., 2005; 8, Ruffo and Stoch, 2006; 9, Cianfanelli et al., 2007; 10, Naselli-Flores et al., 2007; 11, Reitano et al., 2007; 12, Gherardi et al., 2008; 13, Liberto et al., 2010; 14, Marrone et al., 2011; 15, Carminade et al., 2012; 16, Colomba et al., 2013; 17, Di Leo et al., 2014; 18, Bellante et al., 2015; 19, Alfonso and Marrone, upublished data. 
no specimens collected in Sicilian inland waters were, to our knowledge, ever studied or described and whose presence itself in the island is to be considered dubious.

The only aquatic bird ever reported as a NIS for Sicily is the mute swan, Cygnus olor (Gmelin, 1789) (Scalera, 2001). However, the specimens overwintering in Sicily are likely coming from the southern Balkans, where the species is autochthonous as breeding as well as wintering bird, and should therefore be considered autochthonous in Sicily (B. Massa, personal communication).

\section{DISCUSSION}

\section{The animal xenodiversity of Sicilian inland waters}

When comparing the checklists reported in Tabs. 1 to

Tab. 2. List of the non-indigenous vertebrate animal species known to occur in Sicilian inland waters.

\begin{tabular}{|c|c|c|c|c|c|}
\hline Taxon & $\begin{array}{l}\text { Category } \\
\text { allochthonous } v s \\
\text { parautochthonous }\end{array}$ & Origin & $\begin{array}{l}\text { Introduction } \\
\text { intentional } v s \\
\text { unintentional }\end{array}$ & $\begin{array}{l}\text { Status } \\
\text { established vs } \\
\text { sporadic }\end{array}$ & Source(s) \\
\hline $\begin{array}{l}\text { CHORDATA } \\
\text { Osteichthyes } \\
\text { Perciformes } \\
\text { Centrarchidae }\end{array}$ & & & & & \\
\hline $\begin{array}{l}\text { Micropterus salmoides Lacépède, } 1802 \\
\text { Percidae }\end{array}$ & A & North America & I & $\mathrm{E}$ & $7,12,16,17,18,21,25$ \\
\hline $\begin{array}{c}\text { Perca fluviatilis Linnaeus, } 1758 \\
\text { Cypriniformes } \\
\text { Cyprinidae }\end{array}$ & n.a. & Eurasia & I & $\mathrm{E}$ & $2,18,25$ \\
\hline Carassius auratus (Linnaeus, 1758) & n.a. & Asia & I & E & $2,3,6,7,8,16,17,18,21,25$ \\
\hline Cyprinus carpio (Linnaeus, 1758) & $\mathrm{P}^{*}$ & Eurasia & I & $\mathrm{E}$ & $2,3,6,7,16,17,18,21,22,25,27$ \\
\hline Rutilus rubilio Bonaparte, 1837 & $\mathrm{~A}$ & Southern Italy & I & $\mathrm{E}$ & $4,6,7,8,12,16,17,18,28$ \\
\hline $\begin{array}{c}\text { Tinca tinca (Linnaeus, 1758) } \\
\text { Siluriformes } \\
\text { Ictaluridae }\end{array}$ & $P$ & Europe & I & $\mathrm{E}$ & $2,3,6,7,16,17,25$ \\
\hline $\begin{array}{l}\text { Ameiurus melas (Rafinesque, 1820) } \\
\text { Cyprinodontiformes } \\
\text { Poecilidae }\end{array}$ & A & North America & I & $\mathrm{E}$ & $6,7,12,17,18,21,25$ \\
\hline Gambusia holbrooki Girard, 1859 & A & North America & I & $\mathrm{E}$ & $\begin{array}{c}1,3,6,7,8,9,15,16,17,18,21 \\
22,25,27,29\end{array}$ \\
\hline $\begin{array}{c}\text { Esociformes } \\
\text { Esocidae }\end{array}$ & & & & & \\
\hline $\begin{array}{l}\text { Esox cf. lucius }{ }^{\S} \\
\text { Salmoniformes } \\
\text { Salmonidae }\end{array}$ & A & n.a. & I & E & $6,7,12,16,17,25$ \\
\hline Oncorhynchus mykiss Walbaum, 1792 & A & North America & I & $\mathrm{S}$ & $6,7,16,17,18,21$ \\
\hline $\begin{array}{l}\text { Salmo trutta Linnaeus, } 1758 \\
\text { Amphibia } \\
\text { Anura } \\
\text { Pipidae }\end{array}$ & A & Europe & I & E & $7,16,17,18,21,25,26$ \\
\hline $\begin{array}{l}\text { Xenopus laevis (Daudin, 1802) } \\
\text { Reptilia } \\
\text { Testudines } \\
\text { Emydidae }\end{array}$ & A & Africa & I & E & $14,19,20,21,23,24$ \\
\hline Emys orbicularis s.1. & A & Peninsular Italy & I & n.a. & 11,30 \\
\hline $\begin{array}{l}\text { Trachemys scripta elegans (Wied, 1839) } \\
\text { Mammalia } \\
\text { Rodentia } \\
\text { Myocastoridae }\end{array}$ & A & North America & I & $\mathrm{S}$ & 19,22 \\
\hline $\begin{array}{c}\text { Myocastor coypus Molina, } 1872 \\
\text { Muridae }\end{array}$ & A & South America & I & E & $17,19,21$ \\
\hline Rattus norvegicus Berkenhout, 1769 & $\mathrm{P}$ & Asia & $\mathrm{U}$ & E & $10,13,17,19,21$ \\
\hline
\end{tabular}

A, Allochthonous; P, parautochthonous; I, intentional; U, unintentional; E, established; S, sporadic; n.a., not available or not applicable; *its parautochthony considered dubious by Gherardi et al. (2008, and references therein); ${ }^{\S}$ no sound information on the identity of the pikes introduced in Sicily is available (see text); 1, Consoli, 1928; 2, Faranda et al., 1977; 3, Tigano, 1983; 4, Tigano and Ferrito, 1986; 5, Lo Valvo et al., 1993; 6, Ferrito and Tigano, 1995; 7, Tigano and Ferrito, 1996; 8, Russo et al., 1997; 9, Veronesi et al., 1997; 10, Sarà, 1998; 11, Lenk et al., 1999; 12, Russo et al., 1999; 13, Scalera, 2001; 14, Lillo et al., 2005; 15, Duchi, 2006a; 16, Duchi, 2006b; 17, Ruffo and Stoch, 2006; 18, Nocita and Zerunian, 2007; 19, AA.VV., 2008; 20, Faraone et al., 2008; 21, Gherardi et al., 2008; 22, Termine et al., 2008; 23, Lillo et al., 2011; 24, Lillo et al., 2013; 25, Bianco, 2014; 26, Duchi, 2014a; 27, Duchi, 2014b; 28, Duchi, 2014c; 29, Duchi and Miceli, 2014; 30, Vamberger et al., 2015. 
3 with the information currently available in literature (Scalera, 2001; Ruffo and Stoch, 2006; Nocita and Zerunian, 2007; Cianfanelli et al., 2007; Gherardi et al., 2008; Bianco, 2014), a certain decoupling is obvious, with the latter lacking some taxa which are actually present in Sicily, or conversely including others whose presence is dubious or to be excluded for the island. This is to be ascribed to the shortage of studies explicitly focused at investigating Sicilian xenodiversity, with the few existing data scattered among often difficult-to-get pieces of literature. Furthermore, most of the whole-country-scale reviews are focusing on allochthonous taxa only, leaving aside the parautochthonous and translocated species, which are possibly difficult to single out when working on large geographical scales, but which can be easily identified when the study area is of limited extension and geographically well-defined as the present case-study.

The case of bony fishes is emblematic: although they

Tab. 3. Checklist of the taxa whose presence in Sicily and $\backslash$ or whose non-indigenous status is uncertain.

\begin{tabular}{|c|c|c|c|}
\hline Taxon & Origin & Notes & Source(s) \\
\hline $\begin{array}{l}\text { MOLLUSCA } \\
\text { Gastropoda } \\
\text { Lymnaeidae }\end{array}$ & & & \\
\hline \multicolumn{4}{|c|}{ 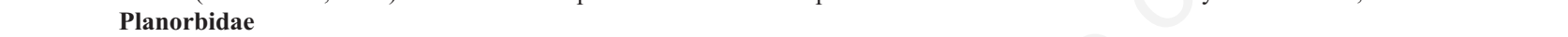 } \\
\hline Helisoma anceps (Menke, 1830) & North America & $\begin{array}{l}\text { It might have been confused with the congener } H . \text { duryi } \\
\text { (cf. Cianfanelli et al., 2007) }\end{array}$ & 5 \\
\hline \multicolumn{4}{|l|}{$\begin{array}{l}\text { Bivalvia } \\
\quad \text { Corbiculidae }\end{array}$} \\
\hline Corbicula fluminea (O.F. Müller, 1774) & Southeast Asia & $\begin{array}{l}\text { The report is based on a single specimen stored in the Mollusc Collection } \\
\text { of the Hebrew University of Jerusalem }\end{array}$ & 2 \\
\hline $\begin{array}{l}\text { CRUSTACEA } \\
\text { Branchiopoda } \\
\text { Anomopoda } \\
\text { Moinidae }\end{array}$ & & & \\
\hline Moina affinis Birge, 1893 & North America & $\begin{array}{l}\text { Possibly a misidentification for the congener species Moina salina } \\
\text { or M. brachiata (cf. Marrone et al., 2005) }\end{array}$ & 1 \\
\hline $\begin{array}{l}\text { CHORDATA } \\
\text { Osteichthyes } \\
\text { Cypriniformes } \\
\text { Cyprinidae }\end{array}$ & & & \\
\hline Carassius carassius Linnaeus, 1758 & Europe & $\begin{array}{l}\text { Taxon reported for Sicily without providing precise locality data } \\
\text { nor relevant references }\end{array}$ & 6 \\
\hline Squalius cf. cephalus ${ }^{\S}$ & n.a. & $\begin{array}{l}\text { Taxon reported for Sicily without providing precise locality data } \\
\text { nor relevant references }\end{array}$ & 4 \\
\hline $\begin{array}{l}\text { Pseudorasbora parva } \\
\text { (Temminck and Schlegel, 1846) } \\
\text { Perciformes } \\
\text { Centrarchidae }\end{array}$ & Asia & $\begin{array}{c}\text { Taxon reported for Sicily without providing precise locality data } \\
\text { nor relevant references }\end{array}$ & 7,8 \\
\hline Lepomis gibbosus (Linnaeus, 1758) & North America & $\begin{array}{l}\text { Taxon reported for Sicily without providing precise locality data } \\
\text { nor relevant references }\end{array}$ & $7,8,9$ \\
\hline \multicolumn{4}{|l|}{$\begin{array}{l}\text { Siluriformes } \\
\text { Ictaluridae }\end{array}$} \\
\hline Ameiurus nebulosus (Lesueur, 1819) & North America & $\begin{array}{c}\text { Taxon reported for Sicily without providing precise locality data } \\
\text { nor relevant references }\end{array}$ & $7,8,9$ \\
\hline $\begin{array}{l}\text { Reptilia } \\
\text { Testudines } \\
\text { Geoemydidae }\end{array}$ & & & \\
\hline $\begin{array}{l}\text { Mauremys cf. sinensis (Gray, 1834) } \\
\text { Aves } \\
\text { Anseriformes } \\
\text { Anatidae }\end{array}$ & Asia & No evidences on the occurrence of the species in the wild are available & 10 \\
\hline Cygnus olor (Gmelin, 1789) & Eurasia & $\begin{array}{c}\text { The individuals overwintering in Sicily might come from the Balkans, } \\
\text { where the species is autochthonous. They should thus } \\
\text { not be considered NIS in Sicily (B. Massa, pers. comm.) }\end{array}$ & 3,4 \\
\hline
\end{tabular}

${ }^{\S}$ No sound information on the species-level identity of the taxon $\backslash$ taxa possibly introduced to Sicily is available; n.a., not available or not applicable; 1 , Faranda, 1977; 2, Mienis, 1991; 3, Lo Valvo et al., 1993; 4, Scalera, 2001; 5, Zettler and Richard, 2003; 6, Duchi, 2006b; 7, Nocita and Zerunian, 2007; 8, Gherardi et al., 2008; 9, Bianco, 2014; 10, Panzeri et al., 2014. 
are by far the most represented non-indigenous taxon occurring in Sicily, only south-eastern Sicilian inland water bodies have been investigated (Ferrito and Tigano, 1995; Duchi, 2006b, and references therein) to date, and nearly no information is available for most of Sicilian inland waters (but see Russo et al., 1999; Duchi, 2014c). As a consequence, no updated local reviews are available, and the Italian lists are rather incomplete or include some taxa whose actual presence in the island is dubious or can be excluded (Ruffo and Stoch, 2006; Nocita and Zerunian, 2007; Gherardi et al., 2008; Tricarico et al., 2010; and, partly, Bianco, 2014). Furthermore, five out of the 11 fish species reported in Tab. 2 are likely translocated taxa from Peninsular Italy, where they are autochthonous, and thus partly or completely overlooked by Nocita and Zerunian (2007), Gherardi et al. (2008), and Bianco (2014). When dealing with biological invasions, the translocation of fish and other animals among different freshwater ecosystems within the region should also be considered. Quite often we actually observed fish introductions in temporary ponds where they can significantly alter and threaten the structure of the native biota (Naselli Flores and Barone, 2012).

The strong predominance of vertebrate over invertebrate taxa in Tabs. 1-3 is likely an artefact due to the high visibility of the former, and to the inadequate number of taxonomists present in Sicily for several aquatic invertebrate taxa. It is quite evident that the presence of a single non-indigenous insect species (i.e., the Asian tiger mosquito, Aedes albopictus) in the list here presented has to be ascribed to the paucity of information currently available on Sicilian inland water insect communities rather than to the actual presence of a single NIS belonging to this important and species-rich taxon. More accurate information is available for inland water molluscs and crustaceans, two among the best-studied invertebrate taxa in Sicily; conversely, no information is available for other important taxa as Porifera, Cnidaria, or Annelida, which include several species known to be introduced in Italian and European inland waters and that might well be present in Sicilian inland waters as well.

In spite of the patent incompleteness of the currently available NIS checklist, seven out of the 31 NIS positively present in Sicilian inland waters are listed among the 100 of the world's worst invasive alien species (Lowe et al., 2000), i.e. one mollusc (the zebra mussel, D. polymorpha), one insect (the Asian tiger mosquito, A. albopictus), three fish (the brown trout $S$. trutta, the carp C. carpio, the large-mouth bass $M$. salmoides), one reptile (the redeared slider, T. scripta elegans), and one mammal (the coypu, $M$. coypus). At least two other heavily invasive species should be added to this list, i.e. the eastern mosquito-fish, Gambusia holbrooki, and the African clawed frog, Xenopus laevis, whose impact on native biotas is largely known and also verified for Sicilian inland waters (Lillo et al., 2011; Duchi and Micieli, 2014). Overall, at least nine highly invasive species threatening the native inland water biota are present in Sicily.

Unfortunately, only few studies have been to date addressed to the evaluation of the impact of NIS on Sicilian native species and ecosystems, and these are mostly dealing with fish (Ferrito and Tigano, 1996; Russo et al., 1999; Duchi, 2006a; Duchi and Micieli, 2014; Duchi et

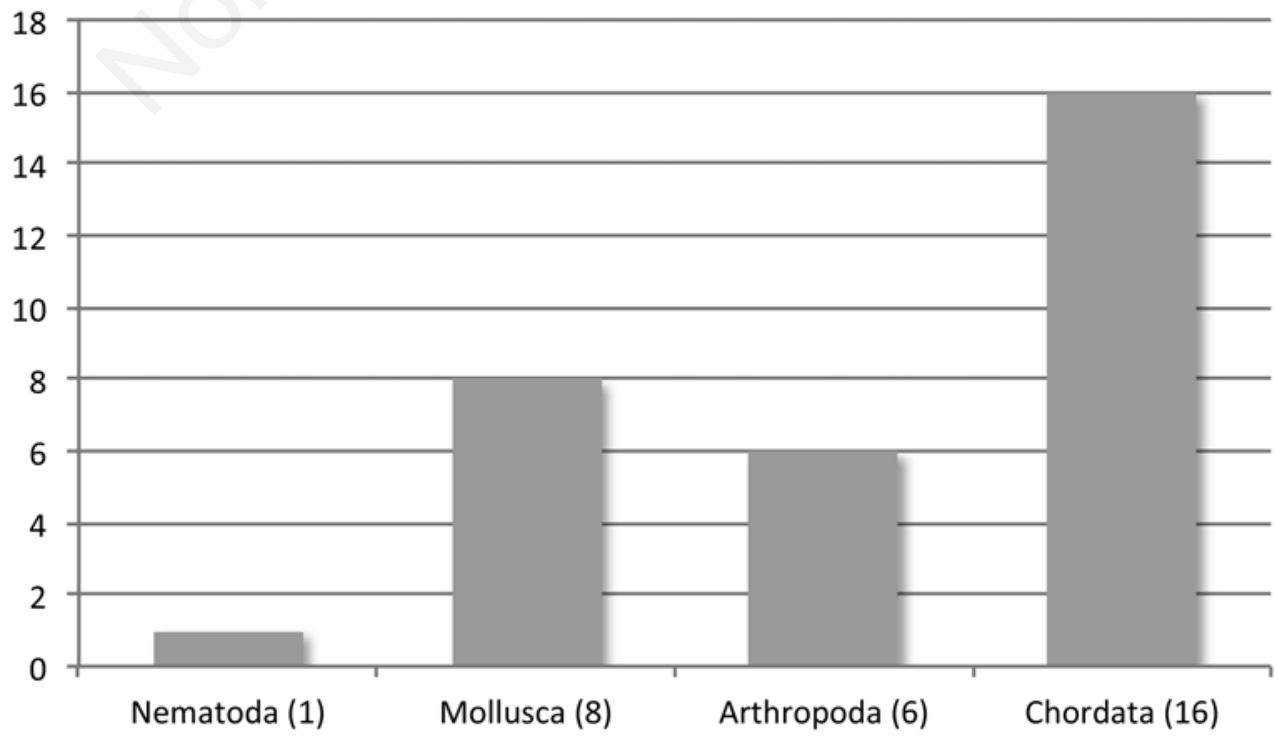

Fig. 1. Histogram of the NIS in Sicilian inland waters by Phylum. Among brackets the number of confirmed species in the island. 
al., 2014a); however, some information on the potential negative role of the red swamp crayfish (P. clarkii) in Sicilian ecosystems as a vector for toxins and heavy metals is available (Naselli-Flores et al., 2007; Bellante et al., 2015), as well as sound evidences on the threats exerted by the African clawed frogs on native amphibians (Faraone et al., 2008; Lillo et al., 2011) (Tab. 4).

\section{Is Sicily a hot-spot for inland water xenodiversity?}

Gherardi et al. (2008) and Tricarico et al. (2010), based on a dataset including only those species which are allochthonous at the whole-country-level (i.e., without considering the parautochthonous and the translocated species), pointed out that Northern Italy is the hot-spot of Italian inland water xenodiversity. Conversely, Boggero et al. (2014), based on a different dataset aimed at exploring the susceptibility to invasions of different habi- tats and regions, found out that the number of alien species (considering only the allochthonous taxa, according to the definitions used in this paper) is a correlate of temperature, so that sites in warmer areas host in average more alien species than those located in colder ones, which is likely due to a more intense touristic frequentation of the former.

The apparent contrast among these results is due to the lacking or inadequacy of sampling surveys and published data for the southern regions of the country: when the mere number of different NIS known to occur in different regions is compared, the best-studied areas (i.e., the central and northern Italian ones) show the higher number of NIS, which is in fact a function of the sampling and publishing efforts rather than a faithful mirror of the actual xenodiversity distribution pattern. Conversely, when a balanced subset of soundly comparable study sites is in-

Tab. 4. Published data on the impact of NIS on the Sicilian autochthonous inland water biota.

\begin{tabular}{lcc} 
Taxon & Recorded impact on the indigenous biota & Source \\
Procambarus clarkii & Vector of toxins and heavy metals to higher trophic levels & Naselli-Flores et al., 2007; Bellante et al., 2015 \\
Micropterus salmoides & Predation on Salaria fluviatilis & Russo et al.. 1999 \\
\hline Gambusia holbrooki & Competition with Aphanius fasciatus & Duchi, 2006a; Duchi and Micieli, 2014 \\
Salmo trutta & Hybridization with Salmo cettii & Duchi, 2014a \\
\hline Xenopus laevis & Predation on indigenous amphibians & Lillo et al., 2011
\end{tabular}

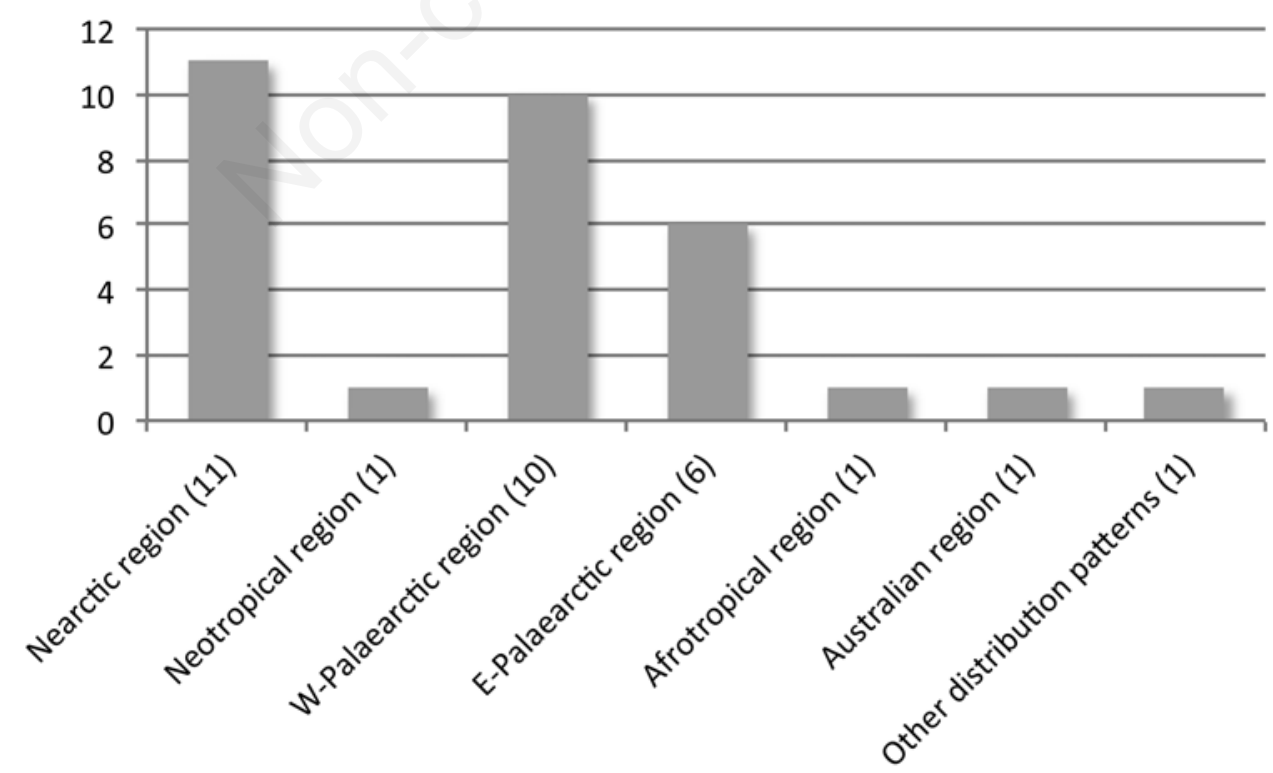

Fig. 2. Histogram of the biogeographical regions of origin for the NIS confirmed in Sicilian inland waters. Among brackets the number of species originating from any biogeographical region. Melanoides tuberculata native range lies in both Afrotropical and Palaearctic regions, and is here reported under the bar named Other distribution patterns. 
vestigated, the result is exactly the opposite, with the warmer southern Italian regions being more prone to be successfully invaded than the central and northern ones. Such a perspective makes even more urgent the need of properly investigating southern Italian and Sicilian inland water biota, possibly an actual but overlooked hot-spot of inland water animal xenodiversity in Europe.

\section{ACKNOWLEDGMENTS}

Bruno Massa (Palermo) is gratefully acknowledged for the comments he provided on the autochthonous status of the mute Swan (Cygnus olor) specimens wintering in Sicily.

Two anonymous reviewers are acknowledged for their comments, which helped to improve a first draft of the manuscript.

\section{REFERENCES}

AA.VV, 2008. Atlante della Biodiversità della Sicilia: vertebrati terrestri. Collana "Studi e Ricerche" 6, Arpa Sicilia, Palermo, $536 \mathrm{pp}$.

Airoldi L, Turon X, Perkol-Finkel S, Rius M, 2015. Corridors for aliens but not for natives: effects of marine urban sprawl at a regional scale. Diversity Distrib. 21:755-768.

Bellante A, Maccarone V, Buscaino G, Buffa G, Filiciotto F, Traina A, Del Core M, Mazzola S, Sprovieri M, 2015. Trace element concentrations in red swamp crayfish (Procambarus clarkii) and surface sediments in Lake Preola and Gorghi Tondi natural reserve, SW Sicily. Environ. Monit. Assess. 187: 404.

Bianco PG, 2014. An update on the status of native and exotic freshwater fishes of Italy. J. Appl. Ichthyol. 30:62-77.

Bianco PG, Delmastro GB, 2011. Recenti novità tassonomiche riguardanti i pesci d'acqua dolce autoctoni in Italia e descrizione di una nuova specie di luccio. Researches on Wildlife Conservation 2:(suppl.)1-13.

Blanchet S, 2012. The use of molecular tools in invasion biology: an emphasis on freshwater ecosystems. Fish. Manag. Ecol. 19:120-132.

Boggero A, Basset A, Austoni M, Barbone E, Bartolozzi L, Bertani I, Campanaro A, Cattaneo A, Cianferoni F, Corriero G, Dŏrr AM, Elia AC, Ficetola GF, Kamburska L, La Porta G, Lauceri S, Ludovisi A, Gaino E, Goretti E, Lorenzoni M, Manca M, Marchetto A, Morabito G, Nonnis Marzano F, Oggioni A, Pierri C, Riccardi N, Rossetti G, Ungaro N, Volta P, Zaupa S, Fontaneto D, 2014. Weak effects of habitat type on susceptibility to invasive freshwater species: an Italian case study. Aquat. Conserv. 24:841-852.

Calvo S, Barone R, Naselli-Flores L, FradàOrestano C, Dongarrà $\mathrm{G}$, Lugaro A, Genchi G, 1993. Limnological studies on lakes and reservoirs of Sicily. Naturalista Siciliano 27(Suppl.):1-292.

Carminade C, Medlock JM, Ducheyne E, McIntyre KM, Leach S, Baylis M, Morse AP, 2012. Suitability of European climate for the Asian tiger mosquito Aedes albopictus: recent trends and future scenarios. J. R. Soc. Interface 9:2708-2717.
Chandra S, Gerhardt A, 2008. Invasive species in aquatic ecosystems: issue of global concern. Aquat. Invasions 3:1-2.

Chytrý M, Jarošík V, Pyšek P, Hájek O, Knollová I, Tichý L, Danihelka J, 2008. Separating habitat invasibility by alien plants from the actual level of invasion. Ecology 89:1541-1553.

Cianfanelli S, Lori E, Bodon M, 2007. Non-indigenous freshwater molluscs and their distribution in Italy, p. 103-121. In: F. Gherardi (ed.), Biological invaders in inland waters: profiles, distribution, and threats. Springer, Dordrecht.

Colomba MS, Liberto F, Reitano A, Grasso R, Di Franco D, Sparacio I, 2013. On the presence of Dreissena polymorpha Pallas, 1771 and Sinanodonta woodiana woodiana (Lea, 1834) in Sicily (Bivalvia). Biodivers. J. 4:571-580.

Consoli, N, 1928. Gl'interventi di piccola bonifica nella lotta contro la malaria in Sicilia. Rivista Sanitaria Siciliana 18, Francesco Sanzo e C., Industria Tipografica Editrice, Palermo: 108 pp.

Cox JG, Lima SL, 2006. Naiveté and an aquatic - terrestrial dichotomy in the effects of introduced predators. Trends Ecol. Evol. 21:674-680.

D'Angelo S, Lo Valvo M, 2003. On the presence of the red swamp crayfish Procambarus clarkii (Girard, 1852) (Decapoda Cambaridae) in Sicily (Italy). Naturalista Siciliano 27:325-327.

Di Leo C, Faraone FP, Lo Valvo M, 2014. A new record of the Red swamp crayfish, Procambarus clarkii (Girard, 1852) (Crustacea, Cambaridae), in Sicily, Italy. Biodivers. J. 5:425-428.

Duchi A, 2006a. Osservazioni sui popolamenti di Nono (Aphanius fasciatus, Valenciennes) e Gambusia (Gambusia holbrooki, Girard) in provincia di Ragusa. Biologia Ambientale 20:73-75.

Duchi A, 2006b. Distribuzione della fauna ittica nelle acque interne dell'areale ibleo: la provincia di Ragusa. Biologia Ambientale 20:291-294.

Duchi A, 2014a. Relazione tra lunghezza e frequenza fenotipica di Salmo cettii/Salmo trutta ed i loro ibridi in un corso d'acqua siciliano (Irminio, Ragusa). Ital. J. Freshwater Ichthyol. 1:207-210.

Duchi A, 2014b. Indagini sulla fauna ittica dei corsi d'acqua presenti in alcuni siti di importanza comunitaria della Piana di Gela (CL, Sicilia, Italia). Ital. J. Freshwater Ichthyol. 1:211214.

Duchi A, 2014c. Ampliamento dell'areale della Rovella (Rutilus rubilio, Bonaparte, 1837) in Sicilia: nuove segnalazioni nell'areale ibleo ed in provincia di Trapani. Ital. J. Freshwater Ichthyol. 1:221-224.

Duchi A, Micieli G, 2014. Prima segnalazione di gambusia Gambusia holbrooki Girard, 1859 (Cyprinodontiformes Poecilidae) nel Pantano Longarini: un fattore di rischio per il popolamento di Nono Aphanius fasciatus Valenciennes, 1821 (Cyprinodontiformes Cyprinodontidae). Naturalista Siciliano 38:115-117.

Ehrenfeld JG, 2010. Ecosystem consequences of biological invasions. Annu. Rev. Ecol. Evol. Syst. 41:59-80.

Elton CS, 1958. The ecology of invasions by animals and plants. University of Chicago Press, Chicago and London (ed. June 2000): $196 \mathrm{pp}$.

Faranda F, 1977. Primo censimento delle aree destinabili ad acquacoltura in Sicilia. Atti Società Peloritana Scienze Fisiche, Matematiche e Naturali 23(Suppl.):1-113 
Faraone FP, Lillo F, Giacalone G, Lo Valvo M, 2008. The large invasive population of Xenopus laevis in Sicily (Italy). Amphibia-Reptilia 29:405-412.

Ferrito V, Tigano C, 1995. The distribution of the ichthyofauna in the Simeto basin (Sicily). Cybium 19:187-198.

Ferrito V, Tigano C, 1996. Decline of Aphanius fasciatus (Cyprinodontidae) and Salaria fluviatilis (Blenniidae) populations in freshwaters of eastern Sicily. Ichthyol. Explor. Freshwaters 7:181-184.

Ficetola F, Thuiller W, Padoa-Schioppa E, 2009. From introduction to the establishment of alien species: bioclimatic differences between presence and reproduction locality in the slider turtle. Diversity Distrib. 15:108-116.

Gazzetta Ufficiale, 2015. Elenco delle specie alloctone escluse dalle previsioni dell'articolo 2, comma 2 -bis, della legge n. 157/1992. Decreto 19 gennaio 2015. Gazzetta Ufficiale della Repubblica Italiana, Serie 31, 07/02/2015, pp 5-6. Accessed on: 27 August 2015. Available from: http://www.minambiente.it/sites/default/files/archivio/allegati/biodiversita/ dim_07_02_2015_specie_alloctone.pdf

Gherardi F, 2006.Bioinvasions in fresh waters and the Nerodilemma. Pol. J. Ecol. 4:549-561.

Gherardi F, 2007. Biological invaders in inland waters: profiles, distribution, and threats. Springer, Dordrecht: 733 pp.

Gherardi F, Bertolino S, Bodon M, Casellato S, Cianfanelli S, Ferraguti M, Lori E, Mura G, Nocita A, Riccardi N, Rossetti G, Rota E, Scalera R, Zerunian S, Tricarico E, 2008. Animal xenodiversity in Italian inland waters: distribution, modes of arrival, and pathways. Biol. Invasions 10:435-454.

IUCN, 2000. IUCN guidelines for the prevention of biodiversity loss caused by alien invasive species. Available from: https://portals.iucn.org/library/efiles/documents/Rep-2000052.pdf

Keller RP, Geist J, Jeschke JM, Kühn I, 2011. Invasive species in Europe: ecology, status, and policy. Environ. Sci. Eur. 23:23.

Lenk P, Fritz U, Joger U, Wink M, 1999. Mitochondrial phylogeography of the European pond turtle, Emys orbicularis (Linnaeus 1758). Mol. Ecol. 8:1911-1922.

Leppäkoski E, Gollasch S, Olenin S, 2002. Alien species in European waters, p. 1-6. In: E. Leppäkoski, S. Gollasch and S. Olenin (eds.), Invasive aquatic species of Europe: distribution, impact and management. Kluwer Academic, Dordrecht.

Liberto F, Giglio S, Reitano A, Colomba MS, Sparacio I, 2010. Molluschi terrestri e dulciacquicoli di Sicilia della collezione F. Minà Palumbo di Castelbuono. Monografie Naturalistiche, 2. Edizioni Danaus, Palermo: 136 pp.

Lillo F, Marrone F, Sicilia A, Castelli G, Zava B, 2005. An invasive population of Xenopus laevis (Daudin, 1802) in Italy. Herpetozoa 18:63-64.

Lillo F, Faraone FP, Lo Valvo M, 2011. Can the introduction of Xenopus laevis affect native amphibian populations? Reduction of reproductive occurrence in presence of the invasive species. Biol. Invasions 13:1533-1541.

Lillo F, Dufresnes C, Faraone FP, Lo Valvo M, Stöck M, 2013. Identification and potential origin of invasive clawed frogs Xenopus (Anura: Pipidae) in Sicily based on mitochondrial and nuclear DNA. Ital. J. Zool. 80:566-573.

Lo Valvo M, Massa B, Sarà M, 1993. Uccelli e paesaggio in Sicilia alle soglie del terzo millennio. Naturalista Siciliano 17 (Suppl.):1-371.
Lowe S, Browne M, Boudjelas S, De Poorter M, 2000. 100 of the world's worst invasive alien species. A selection from the Global Invasive Species Database. Aliens 12:1-12.

Manganelli G, Bodon M, Favilli L, Giusti F, 1995.Gastropoda Pulmonata p. 1-60. In: A. Minelli, S. Ruffo and S. La Posta (eds.), Checklist delle specie della fauna Italiana, 16. Edizioni Calderini, Bologna.

Marr SM, Olden JD, Leprieur F, Arismendi I, Ćaleta M, Morgan DL, Nocita A, Šanda R, Tarkan AS, García-Berthou E, 2013. A global assessment of freshwater fish introductions in mediterranean-climate regions. Hydrobiologia 719:317-329.

Marrone F, Barone R, Naselli-Flores L, 2005. Cladocera (Branchiopoda: Anomopoda, Ctenopoda, and Onychopoda) from Sicilian inland waters: an updated review. Crustaceana 78:1025-1039.

Marrone F, Lo Brutto S, Arculeo M, 2011. Cryptic invasion of a gastropod mollusc in Southern Europe: the case of Ferrissia fragilis (Pulmonata: Ancylidae). Biologia 66:484-490.

Mazza G, Aquiloni L, Inghilesi AF, Giuliani C, Lazzaro L, Ferretti G, Lastrucci L, Foggi B, Tricarico E, 2015. Aliens just a click away: the online aquarium trade in Italy. Management of Biological Invasions 6:253-261.

Mienis HK, 1991. Some remarks concerning Asiatic clams invading Europe with a note on sample of Corbicula fluminea (Mueller, 1774) from Trapani, Sicily. Notiziario SIM 9:137139.

Naiman RJ, Dudgeon D, 2011. Global alteration of freshwaters: influences on human and environmental well-being. Ecol. Res. 26:865-873.

Naselli-Flores L, Barone R, 2012. Phytoplankton dynamics in permanent and temporary Mediterranean waters: is the game hard to play because of hydrological disturbance? Hydrobiologia 698:147-159.

Naselli-Flores L, Barone R, Marrone F, D'Angelo S, 2007. 100 milioni di Microcystis spp. +5 Procambarus clarkii $=0$ Emys trinacris, ovvero tossine, invasori ed estinzione nei Gorghi Tondi, laghi salmastri della Sicilia sud-occidentale, p. 76-77. Proceedings joined Meet. AIOL-SItE, Ancona, Italy.

Nocita A, Zerunian S, 2007. L'ittiofauna aliena nei fiumi e nei laghi d'Italia. Biologia ambientale, 21: 93-96.

Panzeri M, Mori E, Mazza G, Menchetti M, 2014. Records of introduced stripe-necked terrapins (Mauremys species) in Italy. Acta Herpetologica 9:227-230.

Pfenninger M, Schwenk K, 2007. Cryptic animal species are homogeneously distributed among taxa and biogeographical regions. BMC Evol. Biol. 7:121.

Pimentel D, Zuniga R, Morrison D, 2005. Update on the environmental and economic costs associated with alien-invasive species in the United States. Ecol. Econ. 52:273-288.

Reitano A, Liberto F, Sparacio I, 2007. Nuovi dati su Molluschi terrestri e dulciacquicoli di Sicilia. $1^{\circ}$ Contributo (Gastropoda Prosobranchia Neotaenioglossa; Gastropoda Pulmonata Basommatophora, Stylommatophora). Naturalista Siciliano 31:311-330.

Ruffo S, Stoch F, 2006. Checklist and distribution of the Italian fauna. 10,000 terrestrial and inland waters species. Memorie del Museo Civico di Storia Naturale di Verona, serie 2, Sezione Scienze della Vita 17:1-307.

Russo G, Violani C, Zava B, 1997. Observations on population dynamics of Rutilus rubilio Cyprinidae in a man-made hy- 
pertrophic basin (Arancio Lake, southwest Sicily). Ital. J. Zool. 65(Suppl.):549-551.

Russo G, La Rocca S, Violani C, Zava B, 1999. Contributions to the knowledge of Sicilian freshwater fishes. II. Notes on some allochthonous species recently introduced. Doriana $7: 1-7$.

Sarà M, 1998. I mammiferi delle isole del Mediterraneo. L'Epos Società Editrice, Palermo, 166 pp.

Saltonstall K, 2002. Cryptic invasion by a non-native genotype of the common reed, Phragmites australis, into North America. P. Natl. Acad. Sci. USA 99:42445-42449.

Scalera R, 2001. Invasioni biologiche. Le introduzioni di vertebrati in Italia: un problema tra conservazione e globalizzazione. Collana Verde, 103. Corpo Forestale dello Stato. Ministero delle Politiche Agricole e Forestali, Roma: 368 pp..

Simberloff D, 2003. Confronting introduced species: a form of xenophobia? Biol. Invasions 5:179-192.

Simberloff D, Martin JL, Genovesi P, Maris V, Wardle DA, Aronson J, Courchamp F, Galil B, García-Berthou E, Pascal M, Pyšek P, Sousa R, Tabacchi E, Vilà M, 2013. Impacts of biological invasions: what's what and the way forward. Trends Ecol. Evol. 28:58-66.

Sowerby GB, 1873-1874. Monograph of the genus Physa, pp. 27. In: Reeve, Lovell, 1843-78, Conchologica iconica. Vol. 19. Reeve, Benham and Reeve, London.

Stoch F, Valentino F, Volpi E, 1996. Taxonomic and biogeographic analysis of the Proasellus coxalis-group (Crustacea, Isopoda, Asellidae) in Sicily, with description of Proasellus montalentii n.sp. Hydrobiologia 317:247-258.
Termine R, Canale ED, Ientile R, Cuti N, Di Grande CS, Massa B, 2008. Vertebrati della Riserva Naturale Speciale e Sito di Importanza Comunitaria Lago di Pergusa. Naturalista Siciliano 32:105-186.

Tigano C, 1983. Dati preliminari sul popolamento ittico del fiume Simeto (Sicilia). Boll. Acc. Gioenia Sci. Nat. 16:81-98.

Tigano C, Ferrito V, 1986. Sulla presenza di Rutilus rubilio (Bp. 1837) in Sicilia (Pisces, Cyprinidae). Animalia 13:109-124.

Van Bocxlaer B, Clewing C, Mongindo Etimosundja JP, Kankonda A, Ndeo OW, Albrecht C, 2015. Recurrent camouflaged invasions and dispersal of an Asian freshwater gastropod in tropical Africa. BMC Evol. Biol. 15:33.

Veronesi R, Bellini R, Celli G, 1997. Ruolo di Gambusia holbrooki nel contenimento dei culicidi e suo impatto sulle biocenosi acquatiche. Biologia Ambientale 3:24-40.

Vamberger M, Stuckas H, Sacco F, D'Angelo S, Arculeo M, Cheylan M, Corti C, Lo Valvo M, Marrone F, Wink M, Fritz U, 2015. Differences in gene flow in a twofold secondary contact zone of pond turtles in southern Italy (Testudines: Emydidae: Emys orbicularis galloitalica, E. o. hellenica, E. trinacris). Zool. Scripta 44:233-249.

Weidema IR, 2000. Introduced species in the Nordic countries. Nord 13:1-242.

Williamson M, 1996. Biological invasions. Chapman and Hall, London: $224 \mathrm{pp}$.

Zettler ML, Richard D, 2003. Kurze Bemerkungen über Süsswassermollusken Siziliens unterbesonderer Berücksichtigung von Theodoxus meridionalis (Philippi, 1836). Malak. Abh. 21:29.38. 